\title{
AN ANALYSIS OF STUDENTS' HANDWRITING THROUGH GRAPHOLOGY TO MOTIVATE STUDENTS BASED ON ITS LEARNING STYLE
}

\author{
Septiana Rifda Saskia, Hendra, Aa Qonaatun \\ English Education Department, University of Banten Jaya \\ Serang, Indonesia \\ Septiana.ambrose@gmail.com, hendra@unbaja.ac.id, aaqonaatun@unbaja.ac.id
}

\begin{abstract}
The objectives of this study were to find out students' learning styles, character or personality, and learning motivation in English by using graphology as a method of analysis. This research used a qualitative approach. The method used in this research was content analysis. This research was conducted in SMK PGRI 3 Kota Serang with a total of the participant is 10 students. The data was obtained by collecting data of students' handwriting and through the interview of confirming the accuracy of the analysis. The results of this research were: the accuracy of students' characters and personalities is $82,6 \%$ and the accuracy of students' motivation is 77,5\%. As a final result, the average students have standard to high motivation in learning English.
\end{abstract}

Keyword: graphology, handwriting, motivation, learning style, character, and personality

\section{INTRODUCTION}

Writing is one of the media of communication used by humans in representing the language by symbols. Writing is an act or a process of combining some symbols such as a letter of the alphabet, spaces, and characters to express the ideas through written words and in a readable form. Writing is a physical process.

To sum up the definition of writing that had been mentioned above, the purpose of writing is to deliver something which in our minds or in a short way, it is called an expression. An expression is a process of declaring the ideas or thoughts, feelings or emotions, and experiences in order to tell others. The thought is an action that results from the thinking process in which the brain works to manage the information in memory or make concepts/ decisions. The brain sends commands through the nervous system of the arms, hands, and fingers, which then together, the members of the body move and manipulate the writing instrument (Dzulfikar, 2020).

Thoughts reflect on how the way people think. Everyone has different thoughts or ideas. It means every single person has different characters and personalities. Character is the values of human behavior related to God Almighty, oneself, fellow human beings, the environment, and nationality which are 
manifested in thoughts, attitudes, emotions, words, and actions based on religious norms, laws, manners, culture, and customs (Muslich, 2012). In general, personality refers to how individuals appear and make an impression on other individuals. (Setiawan, 2021).

Those characters and personalities can be learned through graphology. Graphology can be defined as a science that can identify, evaluate and understand the character or character of a person through his handwriting patterns (Prasetyo, 2010). Graphology is a method that can measure a person's spontaneity and non- verbal communication that comes from within a person. Handwriting is a unique combination of conscious or unconscious thoughts and feelings (Wahyuni, 2018). It means graphology shows that everyone is unique because of the differences of people's handwriting. Handwriting analysis is something that had been carried out and applied for centuries now which unique, specialized, and emerging scientific process. Nevertheless, the effectiveness and its reliability as a method to find out the personality and behavior is not established and is still a debatable issue (Mahesh \& Nikitha, 2015).

As a teacher, it is a necessary to knowing students' different characters or personality. Every student is unique. The way they learn is different from one another. That is called a learning style (Fleming, 2004). Learning is something that happens naturally and goes unnoticed in most cases. We may think and ponder how a child can do something they previously could not, and we may be amazed at the way a child has developed even in such a short time (Pritchard, 2014).

To obtain or acquire knowledge can be done in several best or preferred ways. Each student has a preferred way of learning and approach that is most suitable for the student. Their success depends not only on how well they learn but on how they learn. Learning style is a way for students to absorb and understand information or ideas. On the other hand, it can be said that the learning style is a preferential way of learning (Hasanah, 2019). It can be known by graphology. The unsuitable method (visual, audio- visual, GTM, etc.) in teaching can be a problem for students understand the subject.

Motivation is a serious issue regarding educational attainment and it also speaks to the type of experience that students are having in school (Elliot, 2020). Each student's experiences may be different from that of other students. This cannot be generalized because the character of each person or in this case is that students are very different. Furthermore, the low 
learning motivation of students in Indonesia in English is a serious problem in the field of education. The reason is that students are always required to do something that is not their motivation, including learning English. Students think that English is a difficult subject to learn so that interest in learning it is very low even though we all know that the use of English today is very important.

The role of English as a foreign language in Indonesia reinforces the fact that students' learning interest or motivation is still very low. Instead of determining English as a crucial language, this language is only considered as a foreign language where its importance had not been given much attention. Even so, the teachers did not run out of minds to keep motivating students to learn foreign languages easily, especially English. Once the teacher understand the learner, it would be easy to design instructional strategies accordingly to make teaching-learning a successful experience (Ahuja, 2018).

This study to obtained focused research results and in accordance with the expected research objectives, there is a limitation on the scope of the research.

This study would focus on analyzing students' writing using graphology to determine student learning styles so that teachers could find out the character of each student more easily without having to ask questions about their background and daily life.

The research would focus on the effectiveness of graphology usage to find out students' learning styles in order to increase the learning motivation and to find out students' characters and personalities.

\section{METHOD}

This research used a qualitative as its approach. This study explained and discovered the relation between the usage of graphology and the improvement of students' motivation. The method was used by this study is content analysis where the writer analyzed students' handwriting as the main point of this study. As for the reference used in this research is the book written by Krippendorf entitled Content analysis: An introduction to its methodology.

"In the 1980s, content analysis was a research method that had entered the psychological and social sciences, but was used mainly in journalism and communication research. At that time, the amount of human effort required to collect, transcribe, and code textual data made content analysis a time-consuming and labor-intensive effort." (Krippendorf, 2004). 
Today, content analysis had become an efficient alternative to public opinion research, a method of tracking markets, political leanings, and emerging ideas; it is used as a way to settle legal disputes and as an approach to the exploration of individual human minds-not to dwell on the many improvements that content analysts have made in traditional content analytic inquiries of the mass media.

In this research, the writer used three types of collecting data. They were note-taking, interview, and analysis of students' handwriting itself (coding). In qualitative research, coding is how you define what the data you are analyzing are about (Gibbs, 2007). Coding is a process of identifying a passage in the text or other data items (photograph, image, and writing), searching and identifying concepts and finding relations between them. Therefore, coding is not just labeling; it is linking of data to the research idea and back to other data.

\section{DISCUSSION}

This research was conducted in SMK PGRI 3 Kota Serang with a total of the participant is 10 students. The data is obtained by collecting data of students' handwriting and through the interview of confirming the accuracy of the analysis. The results of this research, the accuracy of students' characters and personalities is $82,6 \%$. On the other side, the accuracy of students' motivation is $77,5 \%$. As a final result, the average students have standard to high motivation in learning English.

This research took place in one of the vocational high schools in Serang, Banten, SMK PGRI 3 Kota Serang, and it was conducted for five months, starting from April to August.

\section{Analysis of Students' Learning Styles and Characters}

The following is data of students' handwriting and their both learning style categories and characters or personalities:

\section{Visual}

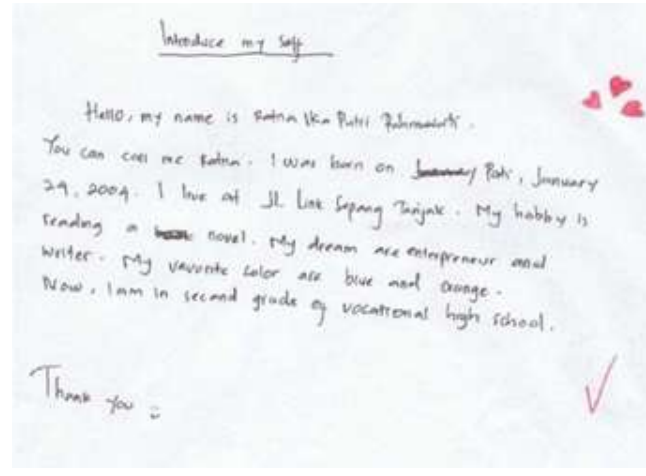

Based on the characteristics given in this handwriting, it can be seen that the writer carved symbols such as symbols of love and smiles (emoticon), and the writer chose specific colors for these symbols/signs. It indicates that the writer has a visual learning style, or through pictures/videos. The writer also has an interest in the art of writing. Therefore, the writer makes these symbols/signs. 
Based on the results of the analysis, writing with a dominant upper and lower zone shows that the writer has a good intellectual, ambitious, strong would, hard worker, and person who is able to organize, as well as a bit of a perfectionist. On the other hand, the negative side of handwriting like this also reflects people who like to fantasize, like to be different from others, and can't respect other people's opinions.

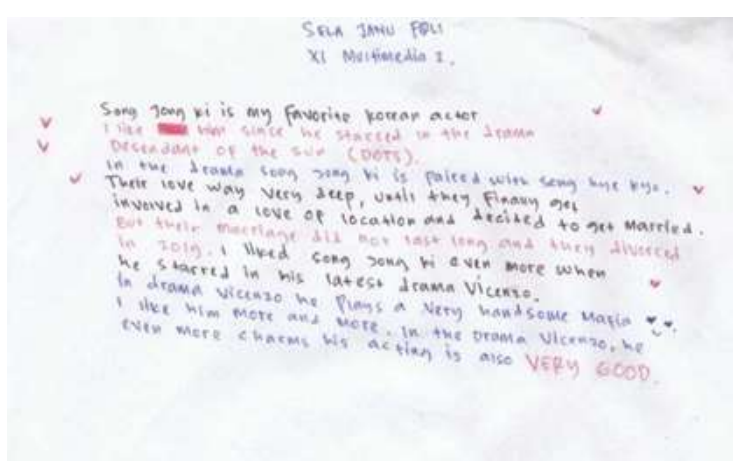

This handwriting indicates that the writer is a student with a visual learning style. This is due to the expressive nature of writing with variations in the color of the pen used in writing; black, red, and blue. Based on the colors used in the paper, it showed that the writer has an interest in something with visual things, such as pictures and videos. It also showed that the writer has a visual learning style.

Based on the handwriting analysis, it can be seen that the writer has a strong desire and is able to determine her attitude for herself so that it seems to be forced so that his wishes can be fulfilled, and this is also what makes the writer not like to be criticized. Having an upper writing zone means the writer has a high concentration and is quite focused but the ideas generated tend to be ordinary. Therefore, the writer also feels that he is small and easily discouraged. The writer is an individualist and likes to be alone. This shows that writers tend to withdraw from the environment and only join when necessary. Based on this, the writer seems to have a slightly arrogant nature and is not easy to approach.

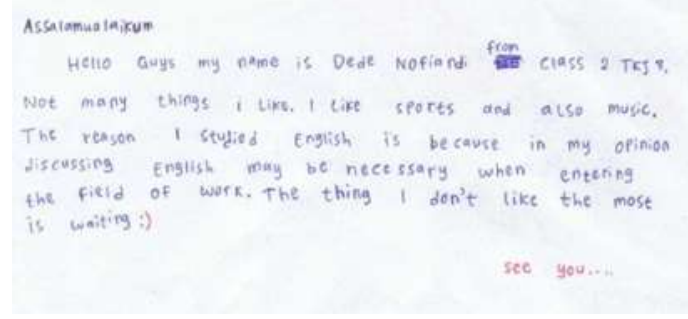

As it is seen from his handwriting, the writer is certainly included in students with visual learning styles. This is because the writer uses a colored pen other than black in making paragraphs. The writer chose blue as the main color in writing. In addition, the writer also uses red at the end of the paragraph. The colors used may be intended to distinguish the opening, main, and closing sections of the paragraphs that have been made. In addition, the writer carved a colon/ symbol and right parentheses ": )" as a sign of a smile. So it can be ascertained that the writer is a student who is expressive and easy to 
understand lessons through visual media such as pictures/ photos/ videos.

Written with an upper zone which means the writer has a fairly high and tenacious intellect. People of this type are people who would like to work hard, are realistic, and have varied interests, and ambitions for something ideal. On the other hand, writers are also the type of people who like to fantasize, find it difficult to understand or make contact with reality. It took a while to think and make the idea clear to others. The writer has an upright and wide writing type that shows independent behavior, good emotions, is confident in his own abilities and is serious, and has calm in dealing with problems/troubles. Due to this, the writer pays little attention to others, is sometimes pessimistic and rigid, and is less responsive.

\section{Auditory}

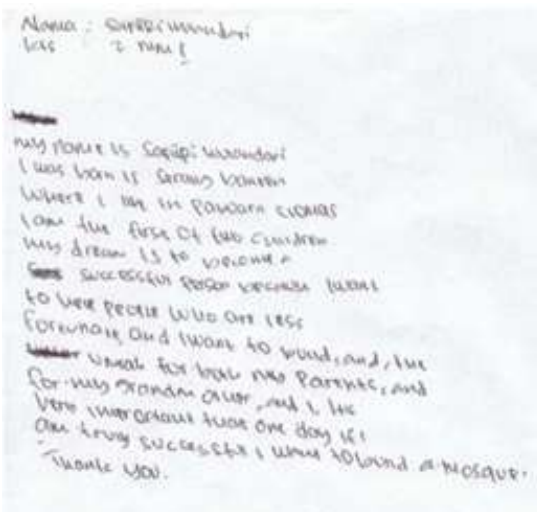

The writer with this handwriting indicates that he is a student who belongs to the auditory category. An analysis based on the absence of symbols or other additional signs, even the color of the writing. The writer uses one color out of the three provided; i.e. black. The hypothesis of this paper shows that the writer is a simple person and does not like to beat around the bush. One of the signs of an auditory student is also being able to describe well. It is seen from how she listened to instructions through speech.

Writing with the upper zone shows that the writer has a good intellectual tendency and has a broad and open minded. The writer is the type of person who works hard, wants little attention or is considered important, and takes a long time to think. The writer is an optimistic person, confident in herself, and does not want to depend on others. However, the writer is also a person who lacks discipline. The writer prefers to be alone and closed, tends to pay attention to herself or those closest to her. The writer has a nature that is too sensitive and afraid to face the future. Therefore, the writer was always careful to avoid any dangers or problems that would come.

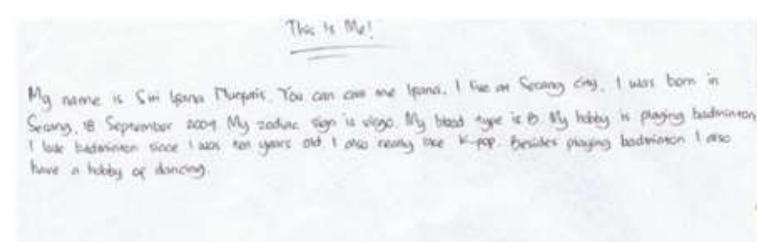

This handwriting explains that the writer has a combination of visual and auditory learning styles. The visual side is 
seen from the use of lines under the titles given above the writing. The number of lines is 2 , accompanied by a quotation mark so as to make the writing clear. The auditory side is seen from the writing that tends to focus. Focus here means that the writer is very concentrated on the time of writing.

Writing with the nature of the lower zone shows that the writer is an organized, calm, analytical, realistic, responsible person, and lives with a clear direction. However, they tend to be stubborn and less able to understand other people. That's the description of the character of the writer with the text above.

Based on her writings, the writer is the type normal and balance, good at carrying herself, and able to control her emotions and follow the rules because her writing tends to be neat. This type is usually able to analyze the strengths and weaknesses that exist in her. This type of writing also shows that the writer is a little closed to social life but likes to observe things.

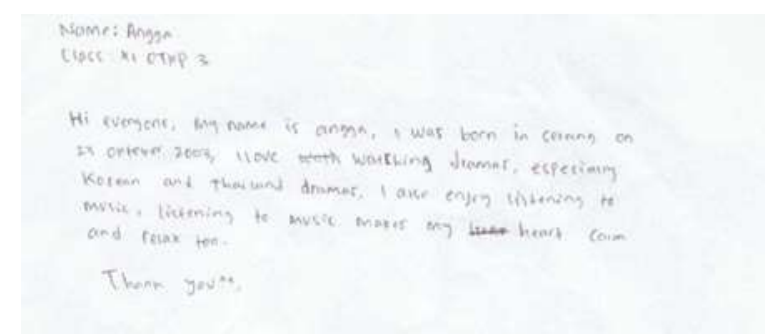

Based on the results of the analysis, the writer is a student with an auditory learning style. This is indicated by the writing that tends to be inexpressive. The meaning of inexpressive is because the writer does not use all the facilities provided by the facilitator as a supporting medium to find out more about the character or learning style.

Handwriting like this characterizes that the writer is a realistic person, has a good balance of life, is not easily influenced, and has a strong desire, and is good at bringing himself into friendship. However, he is also the type of person who closes himself in some conditions or situations, tends to push when his desires are not fulfilled (ambitious), is overconfident, and tends to be impatient. Upright writing indicates a calm, independent attitude, and does not want to depend on others. The writer had a strong enthusiasm at the beginning but experienced a decrease in energy after. Slightly moody (easy temperament and easy to calm down), has spontaneity and definite goals.

The writer has a personality that tends to be feminine. Feminine here means sensitive and sensitive. The writer also has a flexible and humble character, he likes order and simplicity. The negative side of the writer is a bit stiff, sometimes careless, afraid, shy, irritable, bored quickly, and a little cautious. This also strengthens the character of the writer mentioned above, which is not easily influenced. 


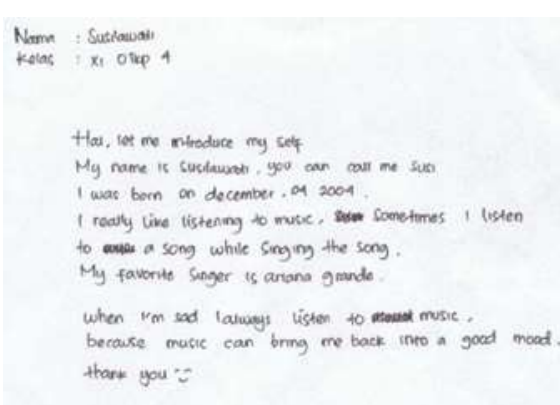

Based on the analysis of his writing, the writer is a student who belongs to the auditory category. This is due to the nature of writing that tends to be less expressive. In this case, the use of symbols/ signs or the usage of colorful pen that has been prepared. Although at the end of the paragraph, the writer adds a sign in the form of a smile, it does not completely make the writer a student with a visual learning style. This is because the writing is dominated by words throughout the paragraph.

Writers with a middle zone have a good balance and can organize, can think analytically and based on facts, are not easily influenced, and have fairly clear life principles. Therefore, writers usually have made certain patterns for themselves so that it is difficult to accept other people's opinions and tends to be selfish. Refers to the point where the writer has a high concentration power and pays attention to detail, the writer tends to prioritize herself but sometimes feels afraid and easily discouraged. The fear here is that if the perfectionist side is not fulfilled, then feel insecure. Based on the statement above, this indicates that the writer is also an independent and calm person and can make realistic decisions. An writer is a person who is consistent and is concerned with living in the present. Everything must go through careful consideration. The writer is the type of person who obeys the rules but does not want to be restrained.

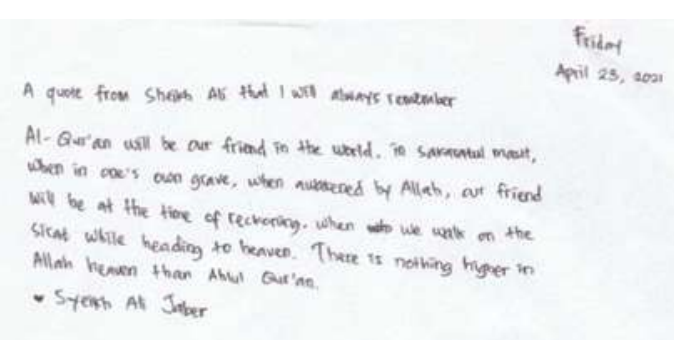

Based on the analysis, the writing which is a quote reflects that the writer is a student who tends to obey the rules or instructions. This can also be seen from the writing pattern that seems short and clear but still directed according to the directions given. At the end of the paragraph, the writer carves a sign/symbol of love, as a symbol of his love for the quote maker. This is also a sign that the writer is a less expressive student. Apart from not using personal ideas, the writer also does not use many signs/ symbols.

Handwriting like the one above reflects a cautious nature, not easily influenced, has a strong would, good balance and fairly stable self-control, and a simple would. However, the writer also has 
a character that is hesitant in making decisions, is afraid to face the future, tends to close herself off from social life, and is closed. The writer also lacks a basic vision of life. The writer has medium-sized writing, which shows that an writer is a person who is, not having a trait that is neither too high nor too low. Usually, this type is good at bringing and adapting to the standards/norms that apply in society. In addition to being of medium size, the writer also has a convex form of writing which means that the writer is the type of person who is excited at the beginning but has decreased energy at the end. In addition, sometimes filled with feelings of doubt and easily feel depressed or hopeless.

\section{Kinesthetic}

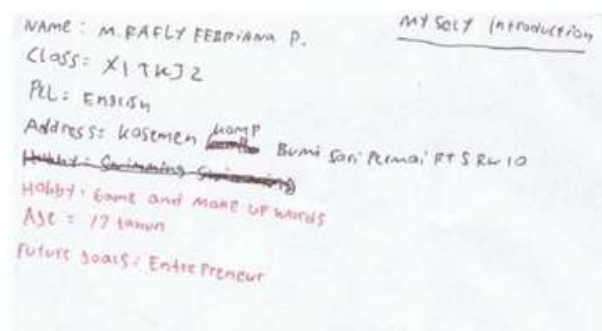

Based on the results of the analysis of this handwriting, it was found that the writer is a student with a kinesthetic learning style, namely students who like to move/be active during learning. This can be seen from the writing that he wrote, the instructions said to make paragraphs, but the writer chose to write in the form of lines. Although the writer chose 2 colors, namely black and red, this does not reflect that the writer is a student with a visual learning style. On the other hand, the written content also looks rushed and less than optimal. It means that the writer does not fully understand the explanation/instructions given through the speech/image examples that have been shown.

People with handwriting like this indicate that the writer has a strong desire and wants to dominate, is not easily influenced, thinks of himself as he is, and has a relatively objective perception.

On the other hand, the writer is a selfish person and does not like to be criticized. The writer sometimes hesitates and quickly becomes depressed and easily discouraged, and is easily influenced by momentary situations. This is what strengthens the evidence that he is less able to make good decisions, tends to be afraid and embarrassed. However, he wants freedom and doesn't want to be bound by certain rules so he usually has the initiative in doing things.

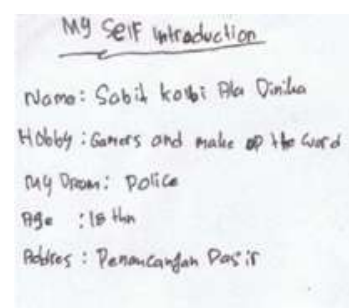

Writers with this type are very difficult to understand the instructions; it can be seen from the writing that is far from 
the impression of a paragraph but in the form of a line. The writer prefers to be involved in physical activity or to demonstrate/describe something directly, not through writing. This short writing characterizes that the writer is a student with a kinesthetic learning style. In addition, the absence of adding emojis/ signs/ symbols is another sign that the writer is a kinesthetic student. The color of the pen used tends to be one black color.

The writer has a small writing size. It shows that the writer has high concentration, low self-esteem, has a spirit of learning, pays attention to details, and thinks before acting. However, unable to see things in a larger aspect, it is necessary to pay attention to formal things (too focused with accuracy). The narrow distance of writing shows that the writer can establish relationships quickly and is quite good at socializing. The writer doesn't like to waste time and he also has great respect. However, the writer would seem selfish and difficult to accept other people's opinions.

\section{Findings of Students' Handwriting and}

\section{Its Motivation in Learning English}

In this section, the writer adjusted the results of the analysis of student writing and the results of interviews conducted to confirm the truth or accuracy of the data resulting from the analysis. It should be noted that the confirmation data had been agreed upon by the informants, and has also used the assistance of other media (website) that could add value to the validity of the analysis data. The use of websites to determine the level of accuracy of student data was considered very helpful in research because the questions displayed are based on experts in their fields so that the accuracy rate of the website is $90 \%$ (http://www.educationplanner.org/students/ $\underline{\text { self-assessments/learning-styles- }}$

quiz.shtml). Here are the following final results of the data:

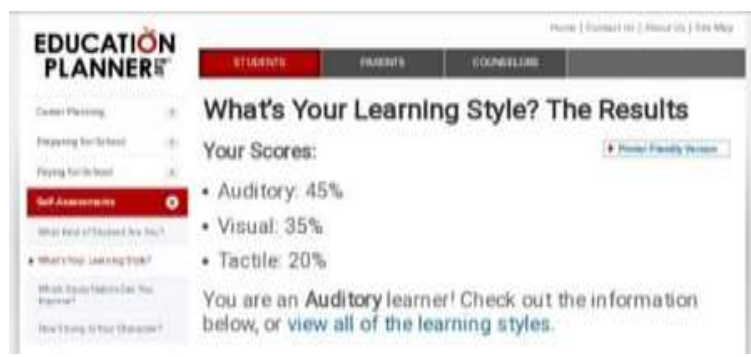

According to the writer's analysis data, there is a discrepancy between the results of the analysis and the results from the website that have been determined at the beginning of the study. Based on the results of the analysis, it was found that the writer was a student with a visual learning style. This is because there are symbols or signs used by the writer such as heart shapes and smile emoticons as well as the use of colors in these symbols. Meanwhile, according to website data, the results show that the writer is a student with an auditory learning style. Thus, to confirm this, the 
researcher asked several questions to ensure her learning style. The writer also said that she tend to look at videos for clarity. For the auditory side, listening to something as well as telling a story is also not a problem for her. This is what makes writers have both of learning styles but tend to be more visual than auditory. As a result, the student confirmed that she has visual learning style in studying.

Furthermore, based on the results of the analysis of students' handwriting to determine their character and personality, the accuracy of the data reached $98 \%$. This is based on points that match their character during the interview process.

Based on the writer's explanation that the writer is an ambitious type of person, explaining that she has a strong motivation both in academic and nonacademic. When she is asked about her motivation to learn English, she answered that her preference for English reached 80\% so that her motivation to learn English is very high.

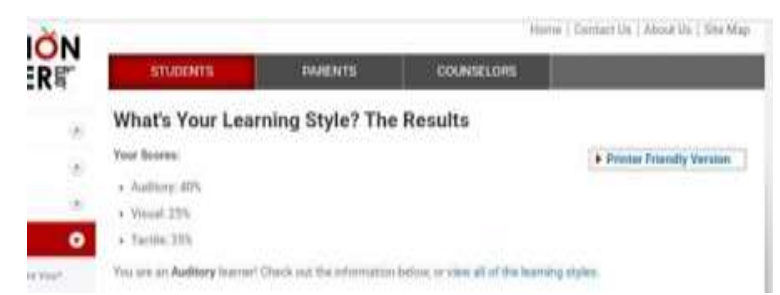

The data are shown above regarding students with auditory learning styles does not match the results of the analysis which states that this handwriting indicates that the student is included in the visual category. This is because writers who tend to express themselves through writing use more than one color. The writer's reason is to maximize her writing by using the 3 colors provided by the facilitator; red, blue, and black. Meanwhile, the use of the heart symbol indicates that the writer feels it is the easiest symbol to draw. The heart symbol used as the eyes in the smile emoticon shows her love for the characters described in the writing. The reason why the writer has a visual learning style is that the writer says that she prefers to learn through video than just through speech. As a result, the student has a visual as her learning style.

Based on the results of interviews on the analysis of student writing, the writer states that the results of the analysis carried out have an accuracy of $80 \%$. This includes learning styles as well as character and personality as well as learning motivation for English subjects. The writer says that she is the type of person who does not push when she has a wish she wants to fulfill. However, if she can do it herself, the writer would try hard to make her wishes come true. Having an introverted nature that makes the writer want to be alone sometimes, but that does not mean that she does not have a balance in friendship. The writer does not like to face challenges but 
has stable emotions, sometimes angry, sometimes it is normal. Based on the results above, it was found that her motivation towards English was not too excited or lazy. It was standard.

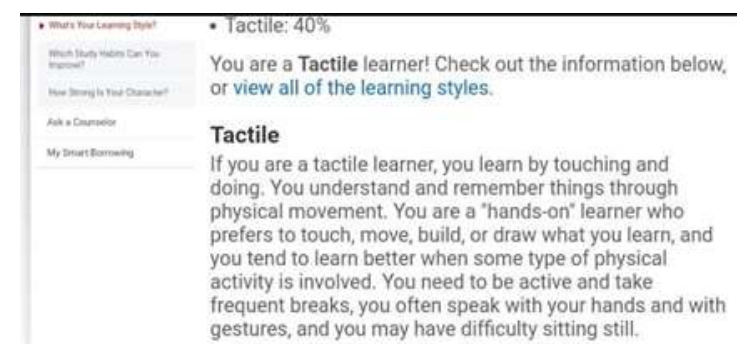

If you look at the results of the analysis, it is found that students have a visual learning style. Meanwhile, based on the results of the data shown in the picture, students have a kinesthetic learning style. Therefore, there is a discrepancy in the data which must be confirmed. Based on what the writer said, it is easier for the writer to learn through pictures. The reason why the three different pen colors provided were not used, was because there was no specific reason but only for variations in writing. Based on this, it can be determined that students have a visual learning style.

However, in the interview session, the writer said that he had an intellectual level at an ordinary or standard level. The writer is the type of person who wants to find out for himself because he feels that what other people say is not necessarily true. The writer has ambition but at a normal level. The writer would do whatever he can. If he feels unable, then he would not do it from the start. The writer always does anything depending on his own abilities, sometimes asking friends for help when experiencing difficulties. The writer has a lack of self-confidence so that he is somewhat closed, tends to seem cautious and alert, and is not easily influenced. Have a mediocre learning motivation, tend to be less. The level of motivation they have in learning English is only $22 \%$.

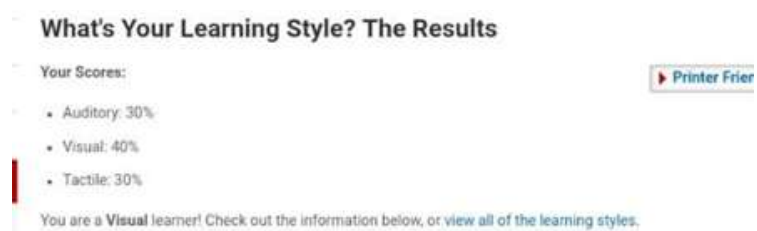

Based on the data analysis performed, the result is auditory. However, referring to the results drawn is visual. Based on the writer's exposure, the writer is the type of person who prefers to listen or learn through sound. The writer is also the type of person who really follows instructions and is to the point. This is an important point that the writer has an auditory learning style.

Based on the analysis of character and personality, a writer is a person who needs a lot of time to think. An writer is a person who lacks discipline, for example when he comes to a place but is not on time or on schedule. Writer is the type of people who pay less attention to the future and tend to think about life in the present. The writer also has a strong desire so that 
whatever is his desire must be obeyed. The writer likes to think about sad things or overthinking and has sensitive feelings.

The writer has a mediocre learning motivation by the percentage is $70 \%$. That is because the writer can follow what is instructed.

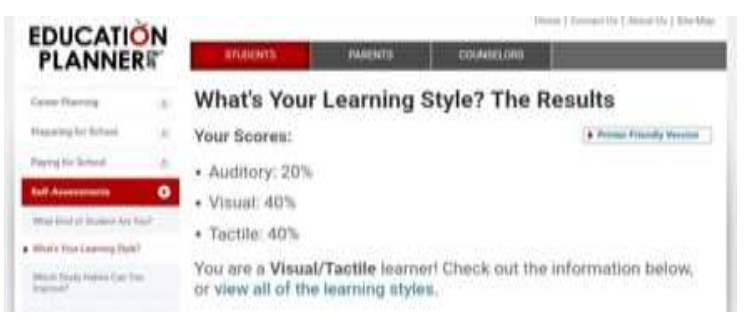

Based on the data analysis, it was found that the writer is a student with a combination of visual and auditory learning styles. This is corroborated by the writer's answer which tends to prefer learning through audio and also when explained directly rather than using visual media. Even so, the writer still has a pretty strong visual side. This is because when asked to describe a cat, the writer answered that what he had in mind was the image of the cat. The writer is a planner, likes to analyze his surroundings, and does not like to waste time. The writer says that she would only leave if she has a clear goal. The writer can find out her strengths and weaknesses, such as having advantages in terms of academics and identifying her weaknesses such as not being able to understand other people's feelings. Writers tend to think about the future. However, sometimes pessimism can come when you start to reflect on the past.

Based on the results of the analysis and interviews, it is known that the writer has high motivation in learning English. It only has general constraints such as vocabulary and grammar.

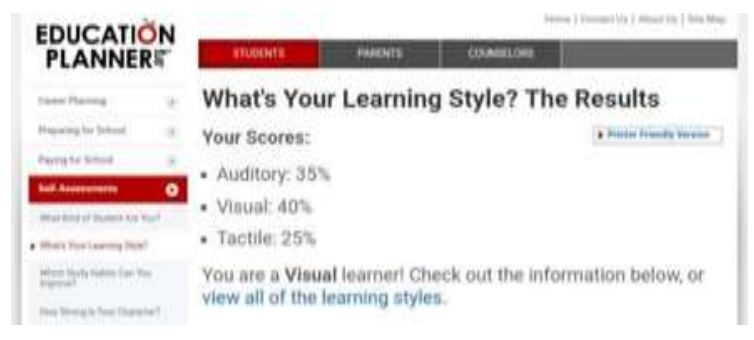

Based on the results, there is a discrepancy between the analysis data and the data from the site. Data analysis states that the writer has an auditory learning style. Meanwhile, the site data shows that the writer has a visual learning style. The writer says that when he writes, his writing does not like to be filled with certain symbols/signs. The writer says that simple writing is better. The writer said that he prefers to listen than to look at the photos because according to him, learning through photos without any explanation would be very difficult. Moreover, it can be ascertained that the writer has an auditory learning style.

The writer says that he prefers to do everything himself and not depend on anyone. According to the writer, regulations are something that must be obeyed. The 
writer has a motivation that tends to be ordinary in learning English.

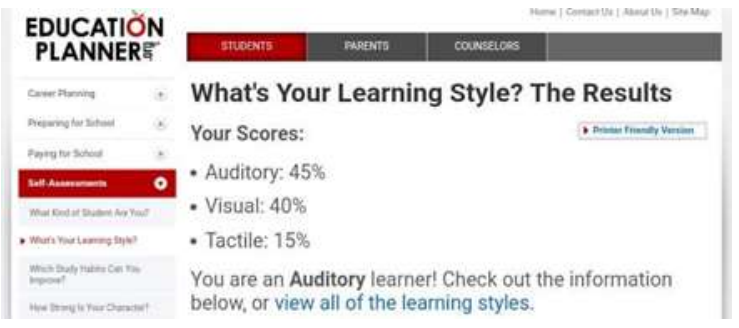

Based on the results, the two data

have something in common, namely

assuming that the writer has an auditory

learning style. This is described by the

writer because the type of student who

prefers to be explained rather than having to

watch alone. The writer says that she

cannot use picture, the writer prefers to hear the teacher's explanation.

The writer is an ambitious person based on her explanation that she always wants to be the best. She would feel insecure and afraid when she faces something better than her. This is supported by her statement that she is a secretary. The writer does not think too much about the future, more inclined to think about the present. Based on the statement above, it can be seen that the writer has high motivation due to the high interest in learning English.

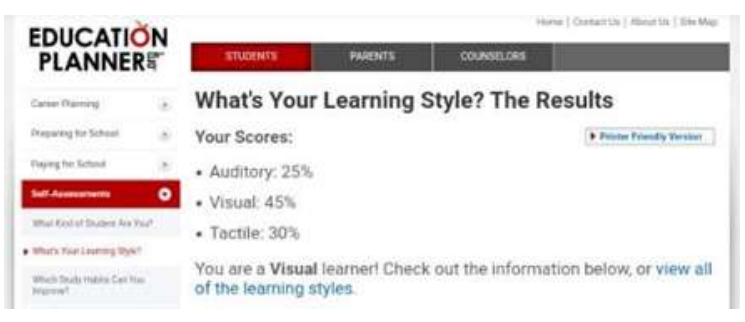

Based on the data between the results of the analysis and the results of the website, it is known that there is a data outage. Previously, the writer gave characteristics such as the writer being included in the auditory category, but after conducting interviews, the results showed that the writer was included in the category of students with visual learning styles. The writer incised a heart symbol with the aim of appreciating the characters in her writing.

The writer is a person who obeys the rules, is simple, and tends to be careful. The writer doubts and fears if the writer makes a mistake. This also explains that the she is afraid to face the future. The writer is a feminine, sensitive, and shy person. The writer is a person who is not very open, tends to be introverted, and only talks to those closest to her. The writer often feel pessimistic and anxious, this is what causes doubts in her. Based on the explanation above, it showed that the writer has an average motivation in learning English. Not too high or too low.

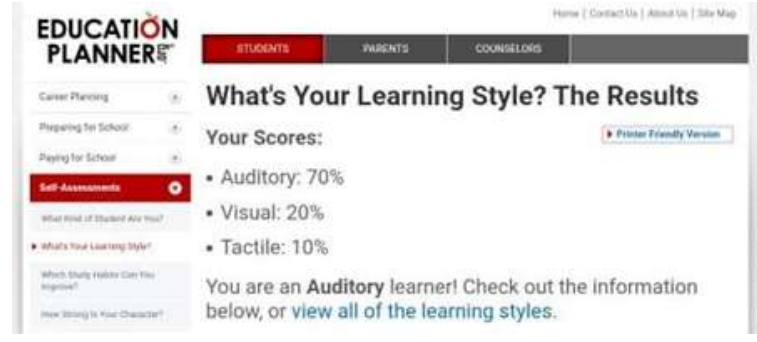

Based on the data taken through the website, there is a discrepancy between the 
results from the site which says that the students fall into the auditory category. Meanwhile, the results of the analysis are that the students with the writing are students with the kinesthetic type of learning or learning through movement/practice. This was then confirmed by the student concerned that he preferred to be involved in the learning process. As a result, student has a kinesthetic learning style.

The writer is a person who is not easily influenced because he has a strong character and has his own mindset. The writer is a person who likes to harbor anger. Writer is also the type of people who think before they act. even so, the feeling of not wanting to be restrained becomes a deficiency in the writer; quitter. The resulting motivation to learn English tends to be normal to low; $50 \%$.

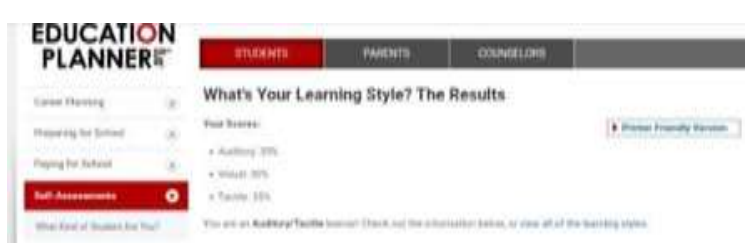

Based on the data, it was found that the synchronous data match between the results of the analysis and the results from the website. Some points that strengthen that the writer is a student with a kinesthetic learning style is that when studying, student tends to learn something more easily through practice or movement or express it directly. The writer said if only use pictures or sound, it would not help students understand. As a result, it is certain that the writer is a student with a kinesthetic learning style.

The writer confirms that he is independent and hardworking and wants to be different from the others. This is corroborated because he also joined organizations. The writer is someone with a personality that is short, solid, and clear (to the point). Although it seems that he pays more attention to himself, the writer also pays attention to others.

The writer is the type of person who obeys the rules but does not like to be restrained. The writer has no difficulty in socializing. This is corroborated by his statement that at this time socializing is important. Meanwhile, before, the writer did not want to start the conversation first (it had smaller writing). The writer has high motivation to learn English. If in percentage, the motivation level is $85 \%$.

\section{CONCLUSION}

Based on the results of data analysis, it can be concluded that the data accuracy between the results of the analysis and interviews reached $82.6 \%$. The percentage value is obtained from the answers to the accuracy of the data per respondent at the time of the interview. 
$\mathrm{P}=\mathrm{x}: 100 \%=82,6 \%$

This can be seen in the table below:

\begin{tabular}{|c|c|c|}
\hline No. & Description & $\begin{array}{l}\text { Accuracy } \\
\text { Character Analysis }\end{array}$ \\
\hline 1 & Student 1 & $98 \%$ \\
\hline 2 & Student 2 & $80 \%$ \\
\hline 3 & Student 3 & $50 \%$ \\
\hline 4 & Student 4 & $80 \%$ \\
\hline 5 & Student 5 & $95 \%$ \\
\hline 6 & Student 6 & $70 \%$ \\
\hline 7 & Student 7 & $97 \%$ \\
\hline 8 & Student 8 & $80 \%$ \\
\hline 9 & Student 9 & $80 \%$ \\
\hline 10 & Student 10 & $96 \%$ \\
\hline & Total & $\mathbf{8 2 , 6} \%$ \\
\hline
\end{tabular}

While the percentage value of students' motivation towards English is $77.5 \%$ with detailed details as follows: 


\begin{tabular}{|c|l|c|l|}
\hline $\begin{array}{c}\text { No } \\
\cdot\end{array}$ & $\begin{array}{l}\text { Descriptio } \\
\mathbf{n}\end{array}$ & $\begin{array}{c}\text { Accuracy } \\
\text { of } \\
\text { Motivation } \\
\text { of } \\
\text { Learning } \\
\text { English }\end{array}$ & Result \\
\hline 1 & Student 1 & $98 \%$ & High \\
\hline 2 & Student 2 & $80 \%$ & Standard \\
\hline 3 & Student 3 & $50 \%$ & Low \\
\hline 4 & Student 4 & $70 \%$ & Standard \\
\hline 5 & Student 5 & $95 \%$ & High \\
\hline 6 & Student 6 & $70 \%$ & Standard \\
\hline 7 & Student 7 & $97 \%$ & High \\
\hline 8 & Student 8 & $80 \%$ & Standard \\
\hline 9 & Student 9 & $50 \%$ & Low \\
\hline 10 & Student 10 & $85 \%$ & High \\
\hline Total & $\mathbf{7 7 , 5 \%}$ & - \\
\hline
\end{tabular}

Table description:

$0-30=$ Very Low

$31-50=$ Low

$51-80=$ Standard

$81-100=$ High

\begin{tabular}{|c|c|c|}
\hline No. & Description & Total \\
\hline 1 & High & 4 \\
\hline 2 & Standard & 4 \\
\hline 3 & Low & 2 \\
\hline
\end{tabular}

In conclusion, as shown in the table, the accuracy of the data and students' motivation to learn English tend to be standard to high.

\section{REFERENCES}

Ahuja, S. 2018. A study of pedagogical practices of successful teachers and its effect on analytical ability application based cognition academic achievement and consciousness. Agra, India: Dayalbagh Educational Institute. Retrieved on 5 February 2021 from https://scholar.google.com/citations $\underline{\text { ?user }=\text { OH2L8IAAAAJ\&hl=en }}$

Dzulfikar, I. 2020. Graphology on the writing of job application at pt. holi karya sakti grobogan. Semarang: Universitas PGRI Semarang. Retrieved on 27 March 2021 from file:///C:/Users/user/Downloads/529 -1671-1-SM(1).pdf

Krippendorff, Klaus. 2004. Content analysis: An introduction to its methodology. Second ed. University of Pennsylvania, US: Sage Publications.

Prasetyo, D., S. 2016. Buku lengkap grafologi: mengenali kepribadian orang melalui tulisan tangan. Yogyakarta: DIVA Press. ISBN: 9786023912698

Wahyuni, S., E. 2018. Graphology for us. Jakarta, Indonesia: PT Elex Media Komputindo. Retrieved on 5 February 2021 from https://books.google.co.id/books?id =iphaDwAAQBAJ\&printsec $=$ frontc over\&dq=Gra phology+for + us \&hl=id\&sa $=X \& v e d$ =2ahUKEwjX28iVo9TuAhVZD3I KHZdDCR0Q

6AEwAHoECAUQAg\#v=onepage 
$\underline{\text { q }=\text { Graphology } \% 20 \text { for } \% 20 \mathrm{us} \& \mathrm{f}=\mathrm{f}}$ $\underline{\text { alse }}$

Website:

Learning Style Test

http://www.educationplanner.org/stude nts/self-assessments/learning-styles-

quiz.shtm 